\title{
Penerapan Pendekatan Kontekstual Berbasis Authentic Assesment Untuk Meningkatkan Hasil Belajar
}

\author{
M.Saipul Watoni \\ STIT Palapa Nusantara \\ e-mail : tony_romanisti@ymail.com
}

\begin{abstract}
Abstrak: Authentic Assesment berfokus kepada tujuan, melibatkan pembelajaran secara langsung, mengharuskan membangun, keterkaitan dan kerja sama, dan menanamkan tingkat berfikir yang lebih tinggi, karena tugas-tugas yang diberikan di dalam penilaian autentik mengharuskan penggunaan strategi-strategi tersebut, maka para siswa bisa menunjukan penguasaannya terhadap tujuan dan kedalaman pemahamannya, dan pada saat yang bersamaan meningkatkan pemahaman dan perbaikan diri. Penelitian ini bertujuan untuk meningkatkan hasil belajar siswa pada mata pelajaran IPS kelas VIII-A SMPN 2 KERUAK Tahun Pelajaran 2017/2018 dengan menerapkan Pendekatan Kontekstual Berbasis Authentic Assssment. Jenis penelitian adalah PTK (Classroom Action Research) yang dilaksanakan dalam 2 siklus. Tiap-tiap siklus terdiri dari 4 tahapan yaitu perencanaan, pelaksanaan tindakan, observasi dan evaluasi serta refleksi, penelitian tindakan kelas ini dikatakan berhasil apabila terjadi peningkatan rata-rata skor hasil belajar siswa pada tiap-tiap siklus meningkat yaitu rata-rata tes hasil belajar meningkat dari rata-rata nilai sebelumnya dan minimal rata-rata nilai mencapai 65 pada siklus akhir. Hasil penelitian menunjukkan bahwa aktifitas dan hasil belajar siswa meningkat, rata-rata hasil belajar siswa pada siklus I dan II berturut-turut adalah rata-rata nilai tes hasil belajar siswa pada siklus I 50,29 atau $40 \%$ dan siklus II rata-rata nilai tes hasil belajar siswa meningkat 91, 42 atau 91,42\%. Indikator keberhasilan tindakan tercapai dapat disimpulkan bahwa penerapan Pendekatan Kontekstual Berbasis Authentic Assssment dapat meningkatkan hasil belajar siswa pada mata pelajaran IPS kelas VIII-A SMPN 2 KERUAK Tahun Pelajaran 2017/2018.
\end{abstract}

Kata kunci: Kontekstual ,authentic assesment, hasil belajar. 


\section{A. Pendahuluan}

Saat ini paradigma pendidikan di Indonesia sudah semakin berkembang dari pendekatan tradisional dimana siswa hanyalah sebagai objek pendidikan, kurang aktif di dalam prosesnya dan gurulah yang menjadi pusat utama dalam pembelajaran, menjadi pendekatan yang lebih modern yang berpusat kepada siswa. Dalam pendekatan ini, siswa aktif merekontruksi pengetahuan yang dimilikinya sedangkan guru hanyalah sebagai fasilitator untuk mengembangkan kemampuan.

Pembelajaran kontekstual sebagai salah satu strategi dalam proses pembelajaran bermula dari pandangan filosofi pembelajaran kontekstual berakar dari paham progresivisme. Intinya, siswa akan belajar dengan baik bilamana apa yang dipelajari oleh mereka berhubungan dengan apa yang telah mereka ketahui, serta proses belajar akan produktif jika siswa terlibat aktif dalam proses belajar di sekolah.

Pembelajaran kontekstual merupakan suatu proses pendidikan yang holistik dan bertujuan memotivasi siswa untuk memahami makna materi pelajaran yang dipelajarinya dengan mengkaitkan materi tersebut dengan konteks kehidupan mereka sehari-hari (konteks pribadi, sosial, dan kultural) sehingga siswa memiliki pengetahuan/keterampilan yang secara fleksibel dapat diterapkan (ditransfer) dari satu permasalahan/konteks ke permasalahan/konteks lainnya. Suatu pendekatan kontekstual pembelajaran mungkin baik untuk satu tujuan, situasi dan kondisi tertentu, tetapi mungkin tepat untuk tujuan, situasi dan kondisis yang lain. Ada pendekatan pembelajaran yang cocok bagi siswa tertentu, akan tetapi kurang serasi bagi siswa lain yang berbeda kepribadiannya .

Seorang guru dalam melaksanakan tugas profesionalnya harus mengetahui berbagai macam model pendekatan sebagai alat bantu dalam proses pembelajaran. Setiap jenis model pendekatan kontekstual dalam pembelajaran hanya cocok atau wajar digunakan dalam situasi belajar tertentu dan untuk mencapai tujuan tertentu. Model penerapan pendekatan tersebut adalah pendekatan kontekstual berbasis Authentic Assesment berfokus kepada tujuan, melibatkan pembelajaran secara langsung, mengharuskan membangun, keterkaitan dan kerja sama, dan menanamkan tingkat berfikir yang lebih tinggi, karena tugas-tugas yang diberikan di dalam penilaian autentik mengharuskan penggunaan strategi-strategi tersebut, maka para siswa bisa 
menunjukan penguasaannya terhadap tujuan dan kedalaman pemahamannya, dan pada saat yang bersamaan meningkatkan pemahaman dan perbaikan diri.

\section{KAJIAN TEORI}

\section{Hakikat Pendekatan Konstekstual}

Menurut Abdurahman pembelajaran dan pengajaran kontekstual adalah suatu pendekatan pembelajaran dan pengajaran yang mengaitkan antara materi yang diajarkan dengan situasi dunia nyata siswadan mendorong siswa membuat hubungan antara pengetahuan yang dimilikinya dengan penerapannya dalam kehidupan mereka sebagai individu, anggota keluarga, masyarakat, bangsa $(2005,137-138) .{ }^{1}$

Menurut Akhmad (2009, 23) pendekatan kontekstual merupakan suatu proses pendidikan yang holistik dan bertujuan memotivasi siswa untuk memahami makna materi pelajaran yang dipelajarinya dengan mengkaitkan materi tersebut dengan konteks kehidupan mereka sehari-hari (konteks pribadi, sosial, dan kultural) sehingga siswa memliki pengetahuan/keterampilan yang secara fleksibel dapat diterapkan (ditransfer) dari satu permasalahan /konteks ke permasalahan/ konteks lainnya. $^{2}$

\section{Komponen Pengajaran dan Penerapan Pendekatan Konstektual di Kelas}

Menurut Abdurrhman (2015, 40-42) pendekatan pembelajaran dan pengajaran kontekstual memiliki komponen-komponen sebagai berikut : konstruktivisme, inkuiri, pertanyaan, masyarakat belajar, pemodelan, refleksi, penilaian autentik. ${ }^{3}$

\section{a. Konstrukivisme}

a.) Membangun pemahaman mereka sendiri dari pengalaman baru berdasarkan pengetahuan awal.

b.) Pembelajaran harus dikemas menjadi proses "merekonstruksi" bukan menerima pengetahuan.

\section{b. Inquiry}

a.) Proses perpindahan dari pengamatan menjadi pemahaman.

\footnotetext{
${ }^{1}$ Abdurrahman, Saleh. 2015. Pendidikan Agama \& Pembangunan Watak Bangsa, Jakarta : PT. Raja Grafindo persada..Hal 137-138

${ }^{2}$ Akhmad, Sudrajat, (2009), Pembelajaran Kontekstua, Jakarta : Depdiknas. Hal 23

${ }^{3}$ Abdurrahman, Saleh. 2015. Pendidikan Agama \& Pembangunan Watak Bangsa, Jakarta : PT. Raja Grafindo persada..Hal 40-42
} 
b.) Siswa belajar menggunakan keterampilan berpikir kritis.

c. Questioning (bertanya)

a.) Kegiatan guru untuk mendorong, membimbing dan menilai kemampuan berpikir siswa.

b.) Bagi siswa yang merupakan bagian penting dalam pembelajaran yang berbasis inquiry.

d. Learning Community (masyarakat belajar)

a.) Sekelompok orang yang terkait dalam kegiatan belajar.

b.) Bekerjasama dengan orang lain lebih baik dari pada belajar sendiri.

c.) Tukar pengalaman dan Berbagai ide

e. Modeling (pemodelan)

Proses penampilan suatu contoh agar orang lain berikir, bekerja dan

belajar serta mengerjakan apa yang guru inginkan agar siswa mengerjakannya

f. Reflection (refleksi)

Cara berpikir tentang apa yang telah kita pelajari, Mencatat apa yang telah dipelajari dan Membuat jurnal, karya seni, diskusi kelompok.

g. Penilaian yang sebenarnya

Mengukur pengetahuan dan keterampilan siswa, Penilaian produk (kinerja) dan Tugas-tugas yang relevan dan kontekstual

\section{Pendekatan Pembelajaran Kontekstual Authentic Assessment}

Dalam kamus bahasa Inggris-Indonesia "Authentic berarti tulisan tangan asli, sedangkan Asssment berarti penaksiran, penilaian” (Andika 2013, 41). ${ }^{1}$ Sedangkan Johnson menjelaskan bahwa authentic assesment berfokus kepada tujuan, melibatkan pembelajaran secara langsung, mengharuskan membangun, keterkaitan dan kerja sama, dan menanamkan tingkat berfikir yang lebih tinggi, karena tugas-tugas yang diberikan didalam penilaian autentik mengharuskan penggunaan strategi-strategi tersebut, maka para siswa bisa menunjukan penguasaannya terhadap tujuan dan

${ }^{1}$ Gulikers \& Andika, (2014), Authentic-Assessment Sebagai-Evaluas, Jakarta : CIA. Hal : 41 
kedalaman pemahamannya, dan pada saat yang bersamaan meningkatkan pemahaman dan perbaikan diri (Najib Sulhan, 2006, 12). ${ }^{2}$

Penilaian autentik menantang para siswa untuk menerapkan informasi dan keterampilan baru dalam situasi nyata untuk tujuan tertentu. Penilaian ini merupakan alat bagi sekolah yang maju, yang tahu dengan jelas apa yang diharapkan dari siswa dan tahu dengan jelas bagaimana mereka mewujudkan kualitas tersebut. Penggunaan penilaian autentik sebagai evaluasi hasil pembelajaran siswa di sekolah merupakan suatu solusi yang bisa ditawarkan untuk melihat sejauh mana pembelajaran yang dilakukan berjalan dengan efektif. Di kedua sisi ini adalah sesuatu yang menguntungkan baik bagi siswa itu sendiri maupun pihak guru atau sekolah. Manfaat bagi siswa adalah dapat mengungkapkan secara total seberapa baik pemahaman materi akademik mereka, mengungkapkan dan memperkuat penguasaan kompetensi mereka, seperti mengumpulkan informasi, menggunakan sumber daya, menangani teknologi dan berfikir sistematis, menghubungkan pembelajaran dengan pengalaman mereka sendiri, dunia mereka dan masyarakat luas, mempertajam keahlian berfikir dalam tingkatan yang lebih tinggi saat mereka menganalisis, memadukan, dan mengidentifikasi masalah, menciptakan solusi dan mengikuti hubungan sebab akibat, menerima tanggung jawab dan membuat pilihan, berhugungan dan kerja sama dengan orang lain dalam membuat tugas, dan belajar mengevaluasi tingkat prestasi sendiri (Nurhadi, 2004, 71). ${ }^{3}$

\section{Prinsip-prinsip Penggunaan Pendekatan Pembelajaran Kontekstual}

\section{Authentic Assessment}

Pada prinsipnya penerapan pendekatan pembelajaran kontekstual Authentic Assesment sama dengan prinsip penerapan pada pembelajaran kontekstual lainnya tapi dalam pendekatan pembelajaran Authentic Assesment dalam proses belajar mengajar lebih menekankan pada penilaian yang sebenarnya yakni ; mengukur pengetahuan

\footnotetext{
2 Sulhan, Najib, (2006), Pembangunan Karakter Pada Anak (Manajemen Pembelajaran Guru Menuju Sekolah Efektif, Surabaya : Intelektual Club Hal : 12

${ }^{3}$ Nurhadi, (2014), Kontekstual dan Penerapannya dalam KBK, Malang : Universitas Negeri Malang Hal 71
} 
dan keterampilan siswa, penilaian produk (kinerja), dan tugas-tugas yang relevan dan kontekstual (Depdiknas, 2000, 23). ${ }^{1}$

Sedangkan Najib Sulhan prinsip bentuk model pembelajaran kontekstual pada intinya yakni :

a. Relating (menghubungkan) dimana, siswa akan belajar dengan menghubungkan pengetahuan yang dipelajarinya dengan pengalaman seharihari dialaminya.

b. Eksperiencing (mengalami), yakni siswa belajar menemukan sendiri dengan daya kreasi, imajinasi, dan inovasi yang mereka miliki.

c. Applying (mengaplikasikan), yakni siswa yang belajar dengan model pembelajaran kontekstual akan mampu mengaplikasikan pengetahuan atau informasi yang telah diperolehnya dalam situasi lain.

d. Cooperating (bekerja sama), yaitu pembelajaran kontekstual akan membuat siswa mampu untuk bekerja sama dengan siswa lainnya. Mereka akan saling menghargai perbedaan pendapat maupun menghargai hasil pekerjaan yang mereka lakukan bersama.

e. Trasfering (memindahkan), yaitu pembelajaran kontekstual akan membuat siswa lebih mahir dengan kemampuan yang dipelajari secara langsung tersebut dan mampu untuk memindahkannya dalam berbagai konteks (2006, 73) ${ }^{2}$

Pendekatan pembelajara berbasis Authentic Assesment berfokus kepada tujuan, melibatkan pembelajaran secara langsung, mengharuskan membangun, keterkaitan dan kerja sama, dan menanamkan tingkat berfikir yang lebih tinggi, karena tugastugas yang diberikan di dalam penilaian autentik mengharuskan penggunaan strategistrategi tersebut, maka para siswa bisa menunjukan penguasaannya terhadap tujuan dan kedalaman pemahamannya, dan pada saat yang bersamaan meningkatkan pemahaman dan perbaikan diri.

\footnotetext{
${ }^{1}$ Depdiknas, (2000), Pendidikan Dalam Proses dan Teknik Pembelajaran, Jakarta. Hal :23

${ }^{2}$ Sulhan, Najib, (2006), Pembangunan Karakter Pada Anak (Manajemen Pembelajaran Guru Menuju Sekolah Efektif, Surabaya : Intelektual Club Hal : 73
} 
Penggunaan penilaian autentik sebagai evaluasi hasil pembelajaran siswa di sekolah merupakan suatu solusi yang bisa ditawarkan untuk melihat sejauh mana pembelajaran yang dilakukan berjalan dengan efektif. Di kedua sisi ini adalah sesuatu yang menguntungkan baik bagi siswa itu sendiri maupun pihak guru atau sekolah. Manfaat bagi siswa adalah dapat mengungkapkan secara total seberapa baik pemahaman materi akademik mereka, mengungkapkan dan memperkuat penguasaan kompetensi mereka, seperti mengumpulkan informasi, menggunakan sumber daya, menangani teknologi dan berfikir sistematis, menghubungkan pembelajaran dengan pengalaman mereka sendiri, dunia mereka dan masyarakat luas, mempertajam keahlian berfikir dalam tingkatan yang lebih tinggi saat mereka menganalisis, memadukan, dan mengidentifikasi masalah, menciptakan solusi dan mengikuti hubungan sebab akibat, menerima tanggung jawab dan membuat pilihan, berhugungan dan kerja sama dengan orang lain dalam membuat tugas, dan belajar mengevaluasi tingkat prestasi sendiri.

Pembelajaran model kontekstual menekankan proses keterlibatan siswa untuk menemukan materi. Prosesnya tidak mengharapkan siswa hanya menerima pelajaran akan tetapi ada proses mencari dan enemukan sendiri materi tersebut. Disamping itu pembelajaran kontekstual juga mendorong siswa untuk menemukan hubungan antara materi yang dipelajarinya dengan kehidupan nyata, artinya siswa dituntut untuk dapat menangkap hubungan antara pengalaman di sekolah dengan kehidupan nyata.

\section{Hasil Belajar}

\section{a. Pengertian Hasil Belajar}

Hasil belajar adalah kemampuan yang dimiliki siswa setelah ia menerima pengalaman belajarnya. Horward Kingsley membagi tiga hasil belajar yaitu, keterampilan dan kebiasaan, pengetahuan dan pengertian, serta sikap dan cita-cita. Sedangkan Gagne membagi lima kategori hasil belajar, yakni informasi verbal, keterampilan intelektual, strategi kognitif, sikap, dan keterampilan motorik (Sudjana, 2008, 22) ${ }^{1}$

Hasil belajar akan meningkat, karena dalam pengajaran kontekstual semua pancaindra siswa diaktifkan dan dimanfaatkan secara serentak dalam proses belajar

\footnotetext{
${ }^{1}$ Sudjana, Nana, (2012), Dasar-dasar Proses Belajar Mengajar, Bandung: Sinar Baru Algensindo. Ha 22
} 
mengajar melalui kegiatan-kegiatan belajar yang lebih (aktual, konkret, realistis, nyata, menyenangkan, dan bermakna (Abdurrhaman, 2015, 138). ${ }^{2}$

\section{METODE PENELITIAN}

\section{A. Jenis Penelitian}

Penelitian ini merupakan Penelitian Tindakan Kelas (PTK) yang dilakukan untuk meningkatkan hasil belajar siswa pada mata pelajaran IPS. Penelitian Tindakan Kelas ini juga dilakukan di kelas (dilakukan dalam pembelajaran biasa bukan diberlakukan dalam kelas khusus) dengan jalan merancang, melaksanakan, dan merefleksikan tindakan secara kolaboratif dan partispatif dengan tujuan untuk menerapkan pendekatan dalam proses pembelajaran sehingga hasil belajar siswa dapat meningkat.

Proses Penelitian Tindakan Kelas dirancang dengan beberapa tindakan siklus dimana setiap siklus terdiri dari 4 tahapan, yaitu: tahap perencanaan, tahap pelaksanaan, tahap observasi, dan tahap refleksi yang diikuti oleh siklus selanjutnya.

\section{B. Subjek dan Objek Penelitian}

a. Subjek Penelitian

Subyek dalam penelitian ini adalah siswa kelas VIII-A-A SMPN 2

KERUAK yang secara keseluruhan berjumlah 35 orang.

b. Objek Penelitian

Yang menjadi objek dari panelitian ini adalah Penerapan Kontekstual Berbasis Authentic Assesment.

\section{Teknik Pengumpulan Data}

Teknik pengumpulan data yang digunakan dalam penelitian ini adalah:

1. Teknik Tes

Tes merupakan salah satu cara yang digunakan peneliti untuk mengumpulkan data penelitian, yang nantinya melalui hasil tes tersebut peneliti dapat mengetahui

\footnotetext{
2 Abdurrahman, Saleh. 2015. Pendidikan Agama \& Pembangunan Watak Bangsa, Jakarta : PT. Raja Grafindo persada..Hal 138
} 
bahwa penerapan pendekatan kontekstual berbasis Authentic Assesment dapat meningkatkan kualitas hasil belajar siswa pada mata pelajaran IPS.

Pengambilan data dengan metode tes diberikan setelah setiap berakhirnya siklus atau melalui hasil tes akhir (post tes). Adapun tes dalam penelitian ini merupakan salah satu cara peneliti gunakan untuk mengumpulkan data mengenai hasil belajar dengan penerapan pendekatan kontekstual berbasis Authentic Assessment untuk meningkatkan hasil belajar siswa pada mata pelajaran IPS kelas VIII-A-A di SMPN 2 KERUAK.

\section{Observasi}

Observasi dilakukan untuk memperoleh informasi tentang kelakuan manusia seperti dalam kenyataan. Observasi yang dimaksud ialah peneliti melihat dan mengamati secara langsung kegiatan proses belajar mengajar dengan menggunakan kontekstual berbasis Authentic Assesment.

Pendekatan kontesktual ini dipandang tepat untuk mengumpulkan data penelitian tindakan kelas. Dalam penelitian ini observasi dilakukan oleh peneliti untuk mengamati prilaku siswa pada saat berdiskusi dan pada saat mengerjakan tugas-tugas Ekonomi yang diberikan baik secara individu maupun kelompok.

\section{Instrumen Penelitian}

Dalam penelitian ini, instrumen yang digunakan adalah sebagai berikut:

1. Tes

Tes adalah serentetan pertanyaan atau latihan serta alat lain yang digunakan untuk mengukur keterampilan, pengetahuan, intelgensi, kemamapuan atau bakat yang dimiliki oleh individu atau kelompok (Arikunto, 2012, 150). ${ }^{1}$ Bentuk tes yang digunakan dalam penelitian ini adalah pilihan ganda, karena bentuk tes ini sangat praktis dan paling luas untuk dijadikan instrument penelitian. Penggunaan tes subjektif dalam penelitian ini dipandang sangat tepat untuk melihat apakah kualitas hasil belajar siswa meningkat atau tidak.

2. Pedoman Observasi

\footnotetext{
${ }^{1}$ Arikunto, Suharsimi, (2012), Prosedur Penelitian Suatu Pendekatan Praktik, Jakarta : Rineka Cipta Hal 150
} 
Supardi mendefinisikan observasi adalah alat pengumpulan data yang dilakukan dengan cara mengamati dan mencatat secara sistematis gejala-gejala yang diselidiki $(2007,88) .^{2}$

Penganalisisan terhadap butir-bulir item tes hasil belajar yang telah diujikan dapat dilakukan dan empat segi yaitu:

a. Validitas Tes.

Yang dimaksud dengan validitas butir adalah butir tes dapat menjalankan fungsi pengukurannya dengan bait atau kecocokan diantara alat ukur atau pengukuran dengan sasaran ukur. Uji validitas tes hasil belajar menggunakan rumus angka kasar sebagai berikut:

$$
r_{x y}=\frac{N \sum X Y-\left(\sum X\right)\left(\sum Y\right)}{\sqrt{\left\{N \sum X^{2}-\left(\sum X\right)^{2}\right)\left(N \sum X^{2}-\left(\sum Y\right)^{2}\right\}}}
$$

$$
\begin{aligned}
& \text { Keterangan: } \quad \mathrm{r}_{\text {hitung }}=\text { Koefisien korelasi } \\
& \sum \mathrm{x}=\text { Jumlah skor item } \\
& \sum \mathrm{y}=\text { Jumlah skor total (seluruh item) } \\
& \mathrm{n}=\text { Jumlah responden (Arikunto, 2011, 72). }{ }^{3}
\end{aligned}
$$

b. Reabilitas Tes.

Tingkat kecocokan antara hasil ukur dengan keadaan sesungguhnya pada responden Reabilitas dikenal juga sebagai taraf kepercayaan pada hasil ukur. Uji reabilitas tes hasil belajar mengounakan rumus Alpha sebagai berikut:

$$
r_{11}=\left(\frac{\mathrm{n}}{\mathrm{n}-1}\right)\left(1 \frac{\sum \delta_{\mathrm{t}}^{2}}{\delta_{\mathrm{t}}^{2}}\right)
$$

$$
\begin{aligned}
& \text { Keterangan : } \mathrm{r}_{11}=\text { Reliabilitas instrument } \\
& \mathrm{k}=\text { Banyaknya soal } \\
& \begin{array}{ll}
\sum \delta_{t}^{2} & =\text { jumlah varian skor tiap-tiap item } \\
\sum \delta_{t}^{2} & =\text { varian total } \quad(\text { Arikunto, 2011, 171) }
\end{array}
\end{aligned}
$$

c. Tingkat Kesukaran.

\footnotetext{
2 Supardi, (2006), Metodologi Penelitian, Mataram Lombok : Cerdas Press.Hal 88

3 Arikunto, Suharsimi, (2011), Dasar-dasar Evaluasi pendidikan, Jakarta : Bumi Aksara. Hal 72

${ }^{1}$ Arikunto, Suharsimi, (2011), Dasar-dasar Evaluasi pendidikan, Jakarta : Bumi Aksara. Hal 171
} 
Adapun rumus untuk menghitung tingkat kesukaran itemnya adalah:

Dimana : $\quad P=\frac{B}{J S}$

$\mathrm{P}=$ Indeks kesukaran

$\mathrm{B}=$ Banyak siswa yang menjawab soal itu dengan benar

JS = Jumlah seluruh peserta test (Arikunto, 2012, 127). ${ }^{2}$

\section{E. Teknik dan Analisis Data}

Teknik analisis data satuan tertentu yang diperhitungkan sebagai subjek penelitian (Arikunto, 2012, 121). ${ }^{3}$ Berikut teknik analisis yang akan dilakukan :

1. Analisis data hasil belajar

Data yang diperoleh dalam penelitian ini akan dianalisis dengan melihat indikator kerja dimana indikator keberhasilan penelitian tindakan kelas ini adalah ketuntasan belajar siswa, dengan kriteria sebagai berikut :

a. Ketuntasan perorangan

Ketuntasan perorangan apabila siswa mampu menyerap minimal 65\% dari materi yang disampaikan oleh guru. Kriteria ketuntasan belajar siswa secara perorangan dapat dihitung dengan rumus :

$$
p=\frac{\text { jumlah skor yang diperoleh }}{\text { jumlah skor maksimal }} \times 100 \%
$$

\section{HASIL PENELITIAN DAN PEMBAHASAN}

\section{A. Hasil Penelitian}

\section{Data Hasil Tes Awal}

Dari instrument penilaian tes awal/pres-tes sebelum penerapan pembelajaran menggunakan pendekatan kontekstual berbasis Authetic Assessment dalam bentuk tes pilihan ganda sebanyak 20 item dan diperoleh hasil dari 35 siswa kelas VIII-A SMPN 2 KERUAK .

\footnotetext{
${ }^{2}$ Arikunto, Suharsimi, (2012), Prosedur Penelitian Suatu Pendekatan Praktik, Jakarta : Rineka Cipta Hal 127

${ }^{3}$ Arikunto, Suharsimi, (2012), Prosedur Penelitian Suatu Pendekatan Praktik, Jakarta : Rineka Cipta Hal 121
} 
Hasil nilai belajar siswa yang belum tuntas mencapai $62,86 \%$ dari 35 jumlah siswa belum mencapai batas ketuntasan yaitu nilai 65, sedang siswa yang telah mencapai nilai 65 ada 13 siswa atau 37,14\% siswa, untuk mengatasi ketidak tuntasan hasil belajar siswa tersebut di atas maka peneliti melakukan pendekatan dalam proses pembelajaran dengan menerapkan pendekatan kontekstual Authentic Assessment.

\section{Data Hasil Siklus I}

Penerapan pendekatan kontekstual Authentic Assessment pada siklus I, diperoleh hasil evaluasi siswa pada siklus I setelah dianalisis diperoleh data sebagai berikut :

Tabel I. Hasil Evaluasi Belajar Siswa Siklus I

\begin{tabular}{|c|c|c|c|c|}
\hline $\begin{array}{c}\text { Jumlah } \\
\text { Siswa }\end{array}$ & $\begin{array}{c}\text { Skor } \\
\text { Tertinggi }\end{array}$ & $\begin{array}{c}\text { Skor } \\
\text { Terendah }\end{array}$ & $\begin{array}{c}\% \\
\text { Ketuntasan } \\
\text { siswa }\end{array}$ & $\begin{array}{c}\% \\
\text { Ketidak tuntasan } \\
\text { siswa }\end{array}$ \\
\hline 35 & 100 & 30 & $40 \%$ & $60 \%$ \\
\hline
\end{tabular}

Dari data tabel tersebut, siswa yang sudah mendapatkan nilai 60 ke atas merupakan batas ketuntasan yaitu 14 siswa atau sebanyak $40 \%$ sedangkan siswa yang belum mencapai batas ketuntasan adalah sebanyak 21 siswa atau sebanyak $60 \%$, berdasarkan hasil tersebut belum tercapainya ketuntasan belajar karena masih banyaknya siswa yang belum mendapatkan nilai 60 ke atas. Dan pada instrument penelitian di Siklus II skor total/ skor kuadrat total mencapai 597 / 3030 dengan hasil validitas $\mathrm{r}_{\text {tabel }}=0,334$ dan $\mathrm{r}_{11}$ 0,84 taraf signifikan $95 \%$ jika kriteria pengujian jika $\mathrm{r}_{\text {bitung }}>$ dari $\mathrm{r}_{\text {tabel }}$ maka instrument reliabel (lampiran 8). Dari analisis data di atas, maka perlu diadakan tindakan penyempurnaan dan perbaikan dalam meningkatkan hasil belajar siswa pada pelajaran IPS dengan pelaksanaan siklus ke II.

3.) Data Hasil Observasi

Data yang diperoleh dalam observasi ini adalah dalam bentuk kualitatif. Pada saat siklus I dilaksanakan peneliti mengamati bahwa ketika proses belajar mengajar berlangsung dengan menggunakan penerapan pendekatan kontekstual Authentic Assessment masih belum maksimal, banyak siswa terlihat kaku dengan bentuk pembelajaran tersebut karena masih dirasakan masih baru dan lebih banyak untuk membaca buku, sekalipun sudah ada siswa yang sudah mulai aktif dalam 
memecahakan masalah. Sedangkan kaitannya dengan hasil belajar siswa pada siklus I ini belum terlalu nampak dengan dilihat dari keaktifan siswa dalam mengeluarkan pertanyaan-pertanyaan dan memberikan umpan balik atas penjelasan guru dan masalah yang ditemukan.

Berdasarkan data observasi guru dan siswa pada siklus I menujukkan adanya peningkatan yang baik, kekurangan pada siklus pertama dapat di atasi, terlihat dari rata-rata persentase aktifitas siswa. Berarti kategori aktifitas siswa dalam pembelajaran siklus I tergolong kurang aktif. Hasil observasi siklus I dapat terlihat pada tabel dibawah ini :

Tabel 2. Hasil observasi aktivitas siswa pada siklus I

\begin{tabular}{|c|c|c|}
\hline Jumlah Siswa & $\begin{array}{c}\text { Rata-rata } \\
\text { Keseluruhan aktifitas siswa }\end{array}$ & Kategori \\
\hline 35 & $10,22 \%$ & Kurang Aktif \\
\hline
\end{tabular}

4.) Refleksi

Dari data hasil evaluasi siklus I dapat diambil kesimpulan bahwa belum tercapainya ketuntasan belajar, sehingga perlu diadakannya penyempurnaan dan perbaikan yang akan di adakan pada siklus II berikutnya. Hal-hal yang perlu diperbaiki pada siklus I adalah sebagai berikut:

Guru harus lebih memotivasi siswa untuk belajar lebih aktif dengan menggunakan penerapan pendekatan kontekstual Authentic Assessment secara maksimal.

- Guru mengarahkan siswa kepada pengembangan materi yang berkaitan dengan kehidupannya sehari-hari agar siswa memahami materi yang sedang diajarkan.

- Membimbing siswa dalam memecahkan masalah yang di suguhkan.

- Guru lebih sering lagi dalam memberikan pertanyaan untuk memancing siswa lebih kritis lagi.

\section{Data Hasil Siklus II}

Dalam siklus II ini juga peneliti menggunakan 4 (empat) tahapan sesuai dengan desain penelitian yang sudah ditetapkan, berikut uraian ke empat tahapan tersebut : 


\section{1.) Perencanaan/Persiapan}

Berdasarkan hasil observasi dan evaluasi pada siklus I masih banyak kekurangan dan hasil belajar siswa sangat rendah, maka pada tahap ini dilakukan dengan memperbaiki kesalahan-kesalahan atau kekurangan-kekurangan pada siklus I dengan cara peningkatan pembelajaran sebelumnya pada pelaksanaan siklus II. Siklus ini merupakan kelanjutan dari siklus sebelumnya yaitu siklus I yang memiliki tujuan untuk meningkatkan hasil belajar siswa dengan penerapan pendekatan kontekstual Authentic Assessment lebih maksimal lagi.

2.) Pelaksanaan tindakan

Proses belajar mengajar siklus II dilaksanakan satu kali pertemuan yaitu tanggal 29 Januari yang dimana pertemuan berlangsung selama 2 x 45 menit dengan standar kompetensi ; memahami kegiatan pelaku ekonomi di masyarakat dan kompetensi dasar mendistribusikan pelaku ekonomi : rumah tangga, masyarakat, perusahaan, koperasi, dan negara. Data hasil yang didapatkan setelah perencanaan dan pelaksanaan tindakan siklus II sebagai kelanjutan dari siklus I, berikut uraian hasil belajar siswa pada siklus II pada tabel di bawah ini :

Tabel 3.Hasil Belajar siswa pada siklus II

\begin{tabular}{|c|c|c|c|c|}
\hline $\begin{array}{c}\text { Jumlah } \\
\text { Siswa }\end{array}$ & $\begin{array}{c}\text { Skor } \\
\text { Tertinggi }\end{array}$ & $\begin{array}{c}\text { Skor } \\
\text { Terendah }\end{array}$ & $\begin{array}{c}\% \text { Ketuntasan } \\
\text { siswa }\end{array}$ & $\begin{array}{c}\% \text { Ketidak } \\
\text { tuntasan siswa }\end{array}$ \\
\hline 35 & 100 & 50 & $91,42 \%$ & $8,58 \%$ \\
\hline
\end{tabular}

Dari data tersebut ada suatu peningkatan dari nilai yang diperoleh dan persentase jumlah siswa yang mencapai batas ketuntasan yaitu ada 32 siswa yang sudah mencapai nilai 65 ke atas atau 91,42\% sedangkan jumlah siswa yang belum mencapai batas ketuntasan adalah 3 siswa atau 8,58\%. Dan pada instrument penelitian di Siklus II skor total/ skor kuadrat total mencapai 597 / 3030 dengan validitas $\mathbf{r}_{11} \quad 0,915$ dan $r_{\text {tabel }}=0,334$ taraf signifikan $95 \%$ jika kriteria pengujian jika $\mathbf{r}_{\text {bitung }}>$ dari $\mathbf{r}_{\text {tabel }}$ maka instrument reliabel (lampiran 15). Karena persentase ketuntasan sudah mencapai minimal 65 bahkan lebih maka pembelajaran pada siklus II dianggap tuntas.

3.) Data observasi 
Berdasarkan pengamatan yang dilakukan diperoleh data kualitatif sebagai berikut :

- Siswa tidak kaku lagi, lebih termotivasi dan aktif (respons) dalam kegiatan belajar setelah penerapan pendekatan kontekstual Authentic Assessment secara maksimal.

- Siswa lebih bisa bekerjasama dalam menyelesaikan masalah dengan temantemannya.

- Siswa lebih banyak lagi dalam memberikan pertanyaan atau sebagai bentuk adanya umpan balik yang menggambarkan kemampuannya.

- Hasil belajar siswa menjadi meningkat dibandingkan dengan hasil belajar pada siklus I.

Berdasarkan data observasi guru dan siswa pada siklus II menujukkan adanya peningkatan yang baik, kekurangan pada siklus pertama dapat diatasi, terlihat dari rata-rata persentase aktifitas siswa. Berarti kategori aktifitas siswa dalam pembelajaran siklus II tergolong aktif. Hasil observasi siklus II dapat terlihat pada tabel dibawah ini

Tabel 4

Hasil observasi aktifias siswa pada siklus II

\begin{tabular}{|c|c|c|}
\hline $\begin{array}{c}\text { Jumlah } \\
\text { Siswa }\end{array}$ & $\begin{array}{c}\text { Rata-rata } \\
\text { Keseluruhan aktifitas siswa }\end{array}$ & Kategori \\
\hline 35 & $14,52 \%$ & Aktif \\
\hline
\end{tabular}

Dari tabel di atas di dapat bahwa rata-rata persentase aktivitas siswa pada siklus II sebesar 14,52 \%. Berdasarkan penggolongan aktivitas siswa siklus II tergolong aktif.

4.) Hasil Refleksi Pembelajaran

Dengan melihat penerapan pendekatan kontekstuan Authentic Assesment secara maksimal dan hasil belajar siswa yang sudah memenuhi kriteria yang telah ditetapkan sejak awal yaitu tinggi sudah dapat terpenuhi, yang mana pelaksanaannya dilakukan dalam II siklus, dan pada siklus ke dua sudah mencapai hasil yang diinginkan maka peneliti tidak perlu lagi melakukan proses pembelajaran ke siklus berikutnya. 
Berdasarkan perolehan nilai pada pelaksanaan siklus I dan siklus II, perbandingan nilai dapat dilihat pada tabel sebagai berikut / tabel tabulasi data.

Tabel 5

Perbandingan Frekuensi Nilai Siklus I dan Siklus II

\begin{tabular}{|c|c|c|c|c|}
\hline \multirow{2}{*}{ No } & \multirow{2}{*}{ Frekuensi Nilai } & \multicolumn{2}{|c|}{ Perbandingan Nilai } & \multirow{2}{*}{ Kategori } \\
\cline { 3 - 4 } & & Siklus I & Siklus II & \\
\hline 1 & $75-100$ & 7 & 28 & Baik \\
\hline 2 & $65-74$ & 7 & 4 & Cukup \\
\hline 3 & $55-64$ & 21 & 3 & Kurang \\
\hline \multicolumn{2}{|c|}{ Jumlah } & 35 & 35 & \\
\hline \multicolumn{2}{|c|}{ Total nilai keseluruhan/total } & $333 / 1760$ & $597 / 3030$ & \\
\hline \multicolumn{2}{|c|}{ Persentase ketuntasan belajar } & $40 \%$ & $91 \%$ & \\
\hline
\end{tabular}

Dari hasil tabel frekuensi dapat diketahui bahwa pada Siklus I dengan nilai antara 55- 64 dengan kriteria "kurang" berjumlah 21 orang siswa, 65-74 dengan kriteria "cukup" mencapai 7 siswa, dan dari 75-100 mencapai kriteria "baik" mencapai 7 siswa dengan nilai ketutasan mencapai $74 \%$. Jadi, persentase ketuntasan belajar (KB) pada siklus I jumlah nilai akhir 333/1760 dan nilai rata-rata kelas 50,29 dengan pesentase ketuntasan belajar mencapai $40 \%$. Dan pada Siklus II perolehan nilai di atas mengalami peningkatan sebanyak 3 orang siswa nilai ketuntasan belajar rata-rata jumlah nilai dari 55 - 64 dengan kriteria "kurang" berjumlah 3 orang siswa, 65 - 74 dengan kriteria "cukup" mencapai 4 siswa, dan dari 75 - 100 mencapai kriteria "baik" mencapai 28 siswa. Jadi, pada siklus II mencapai peningkatan dengan persentase ketuntasan belajar (KB) $91 \%$ dengan nilai akhir 597/3030 dan nilai ratarata kelas 86,58 .

Secara keseluruan dapat disimpulkan bahwa dengan penerapan pendekatan kontekstual Authentic Assessment dapat meningkat hasil belajar siswa kelas VIII-A A SMPN 2 KERUAK.

\section{PEMBAHASAN}


Dari data hasil evaluasi tersebut terjadi suatu peningkatan dari proses pemberian pre-tes sampai siklus II, Pada siklus I atau setelah diberikannya tindakan terjadi suatu peningkatan hasil belajar yaitu siswa banyak yang mencapai batas ketuntasan kalau dibandingkan dengan hasil dari pre- tes dan hanya sedikit dari para siswa yang aktif dalam proses pembelajaran serta dalam menyelesaikan masalah yang disuguhkan dan memberikan umpan balik sebagai gambaran kemampuan hasil belajar siswa serta dalam siklus I ini belum ada siswa yang mampu mengaitkan materi IPS khususnya pelajaran bidang Ekonomi, sekalipun adanya sedikit peningkatan tetapi belum mencapai batas minimal, oleh sebab itu perlu dilakukan perbaikan pada siklus II.

Pada siklus II ini kebanyakan siswa sudah terlihat aktif, mampu untuk menginterpretasikan penjelasan dan masalah-masalah yang di suguhkan oleh guru, dan timbulnya umpan balik (respons) antara guru dan siswa.

Karena sudah mencapai batas ketuntasan minimal dan adanya peningkatan dari hasil belajar siswa pada siklus II maka penelitian tindakan kelas ini sudah dikatakan tuntas serta sesuai dengan salah satu tujuan penelitian tindakan kelas yang di kemukakan oleh Suhardjono dalam (Asrori,2007) yaitu meningkatkan mutu isi, masukan, proses, serta hasil pendidikan dan pembelajaran di sekolah, jadi penerapan pendekatan kontekstual Authentic Assessment mampu meningkatkan hasil belajar siswa pada mata pelajaran IPS siswa kelas VIII-A-A SMPN 2 KERUAK Tahun Pembelajaran 2017/2018

\section{SIMPULAN}

Pendekatan kontekstual Authentic Assesment dalam meningkatkan hasil belajar siswa pada mata pelajaran IPS Terpadu kelas VIII-A-A SMPN 2 KERUAK Tahun Pelajaran 2017/2018. Yaitu setelah penerapan pendekatan kontekstual Authentic Assesment di kelas VIII-A di peroleh hasil belajar siswa pada siklus I dengan nilai ratarata siswa 50,29, persentase ketuntasan mencapai $40 \%$ dan pada siklus ke II meningkat dengan nilai rata-rata siswa 86,58, persentase ketuntasan mencapai $91 \%$. Dari perbandingan nilai siklus I dan siklus ke II yang telah mencapai ketuntasan setelah penerapan pendekatan kontekstual Authentic Assessment para siswa cukup aktif sehingga dapat disimpulkan bahwa dengan penerapan pendekatan kontekstual 
Authentic Assessment dapat meningkatkan hasil belajar siswa pada mata pelajaran IPS Terpadu kelas VIII-A SMPN 2 KERUAK Tahun Pelajaran 2017/2018.

\section{DAFTAR PUSTAKA}

Abudurrhaman, Saleh, (2005) Pendidikan Agama \& Pembangunan Watak Bangsa, Jakarta : PT. Raja Grafindo persada.

Akhmad, Sudrajat, (2009), Pembelajaran Kontekstua, Jakarta : Depdiknas.

Arikunto, Suharsimi, (2012), Prosedur Penelitian Suatu Pendekatan Praktik, Jakarta : Rineka Cipta.

Arikunto, Suharsimi, (2011), Dasar-dasar Evaluasi pendidikan, Jakarta : Bumi Aksara. jamarah, Syaipul Bahri, (2012), Strategi Belajar Mengajar, Jakarta: Asdi Mahasatya. Gulikers \& Andika, (2004), Authentic-Assessment Sebagai-Evaluas, Jakarta : CIA.

Sudjana, Nana, (2012), Dasar-dasar Proses Belajar Mengajar, Bandung: Sinar Baru Algensindo.

Nurhadi, (2014), Kontekstual dan Penerapannya dalam KBK, Malang : Universitas Negeri Malang (UMPRESS).

Sulhan, Najib, (2006), Pembangunan Karakter Pada Anake (Manajemen Pembelajaran Guru Menuju Sekolah Efektif, Surabaya : Intelektual Club.

Supardi, (2006), Metodologi Penelitian, Mataram Lombok : Cerdas Press.

Sugiyono, (2006), Metode Peneliltian Kuantitatif, Kualitatif dan R\&D, Alfabeta : Bandung. Slameto, (2003), Belajar dan Faktor-faktor yang Mempengarubinya, Jakarta : Rineka Cipta, 